\title{
PENGARUH KOMUNIKASI DAN GAYA KEPEMIMPINAN TERHADAP MOTIVASI DAN KEPUASAN KERJA PEGAWAI BAKTI PADA SEKRETARIAT DPRK LHOKSEUMAWE
}

\author{
Yusrizal, A. Hadi Arifin, Naufal Bachri \\ PPIM Universitas Malikussaleh, Lhokseumawe
}

\begin{abstract}
This study aims to observe the influnce of communication and leadership style to motivation and job satisfaction of employee salaries on Lhokseumawe secretariat the council representative people. This research is a quantitative research described by description. The instrument of data collection is a questioner. The sample of this research is 123 employee salaries on Lhokseumawe secretariat the council representative people. Data analysis method used is AMOS-22 program with SEM and Sobel test model. The result of data analysis get some findings as follows those are communication has a positive and significant effect to motivation, leadership style has a positive and significant effect to motivation, communication has a positive and significant effect to job satisfaction, leadership style has a positive and significant effect to job satisfaction, motivation has a positive and significant effect to job satisfaction, motivation mediates fully the influence between communication to job satisfaction, motivation mediates partially the influence between leadership style to job satisfaction.
\end{abstract}

\section{Keywords: Communication, Leadership Style, Motivation, Job Satisfaction}

\section{PENDAHULUAN}

Manajemen sumber daya manusia merupakan suatu ilmu manajemen yang secara khusus mempelajari hubungan peranan manusia dalam berorganisasi dengan kata lain fokus utama dari ilmu manajemen sumber daya manusia adalah mengkaji karakteristik dan segala seluk beluk manusia dalam berorganisasi dari hal tersebut dapat ditarik kesimpulan bahwa Ilmu Manajemen Sumber Daya Manusia adalah bagaimana manajemen mengatur terhadap tenaga kerja atau pegawai dalam berorganisasi.

Menurut Robbins (2006) pada dasarnya sumber daya manusia merupakan serangkaian tindakan dalam hal penarikan tenaga kerja, seleksi tenaga kerja, pengembangan, pemeliharaan, dan penggunaan sumber daya manusia untuk mencapai tujuan individu maupun tujuan organisasi. Organisasi adalah kesatuan sosial yang dikoordinasikan secara sadar, dengan batasan-batasan yang relatif dapat diindentifikasikan, dan bekerja secara berkesinambungan dalam mencapai suatu tujuan (Robbins, 2006). semakin kompleks dan kompetitif dalam berbagai bidang khususnya kehidupan berorganisasi, hal yang sangat penting untuk diperhatikan adalah sumber daya manusia, karena ditangan manusialah tujuan organisasi dapat tercapai dengan baik. Dengan demikian masalah departemen sumber daya manusia merupakan masalah yang kompleks bagi organisasi, dibandingkan dengan departemen lainnya.

Salah satu upaya yang dilakukan adalah menciptakan kehidupan organisasi yang kondusif di mana satu di antara elemennya adalah kepuasan kerja karyawan yang berada pada organisasi tersebut 
(Dewi, 2005). Kepuasan kerja pada dasarnya merupakan hal yang bersifat individual, setiap individu akan memiliki kepuasan yang berbeda-beda sesuai dengan sistem nilai yang berlaku pada dirinya. Hal ini disebabkan oleh adanya perbedaan kebutuhan pada masing-masing individu. Semakin banyak aspekaspek dalam pekerjaan yang sesuai dengan keinginan individu tersebut, maka semakin tinggi kepuasan yang dirasakannya, demikian pula sebaliknya. Kepuasan kerja sebagai sekumpulan perasaan, kepuasan kerja bersifat dinamis, dapat menurun dan timbul pada waktu dan tempat yang berbeda.

Dengan adanya rasa kepuasan dalam bekerja maka individu akan menampilkan pribadi yang baik dalam organisasi, kinerja positif yang memuaskan perusahaan dan timbul kesediaan untuk mengusahakan tingkat produktivitas kerja yang tinggi bagi kepentingan organisasi dan demi memperlancar pencapaian tujuan organisasi. Adapun beberapa hal yang dapat diidentifikasikan dari adanya ketidakpuasan itu adalah ketidakhadiran di tempat kerja, malas, kurangnya motivasi, mangkir dari pekerjaan, peristiwa pemogokan, penggunaan waktu yang tidak efisien.

Faktor kepemimpinan, dari atasan dapat memberikan pengayoman dan bimbingan kepada pegawai dalam menghadapi tugas dan lingkungan kerja yang baru. Pemimpin yang baik akan mampu menularkan optimisme dan pengetahuan yang dimilikinya agar pegawai yang menjadi bawahannya dapat melaksanakan pekerjaan dengan baik. Gaya kepemimpinan merupakan perilaku pemimpin yang digunakan seseorang ketika ingin mempengaruhi orang lain. Menurut Robert House sebagaimana dikutip oleh Robbins (2007) mengungkapkan bahwa terdapat empat macam klasifikasi kepemimpinan Path Goal, yakni gaya kepemimpinan direktif, gaya kepemimpinan suportif, gaya kepemimpinan partisipatif, dan gaya kepemimpinan berorientasi pada tugas. Bermacam-macam gaya kepemimpinan dapat digunakan oleh seorang pemimpin untuk mempengaruhi dan memotivasi bawahannya serta tercapainya kepuasan kerja pegawai, sehingga dapat meningkatkan kinerja bawahannya dalam melakukan pekerjaan. Gaya kepemimpinan yang tepat akan menimbulkan motivasi seseorang untuk berprestasi. Sukses tidaknya karyawan dalam prestasi kerja dapat dipengaruhi oleh gaya kepemimpinan atasannya (Regina, 2010).

Selain itu dalam melaksanakan pekerjaan, komunikasi juga tidak terlepas dari kepemimpinan suatu organisasi baik itu komunikasi dengan Pimpinan maupun komunikasi dengan sesama rekan kerja. Komunikasi yang digunakan sebagai sarana setiap individu dalam memperluas wawasannya melalui jalur-jalur informasinya. Ini artinya, komunikasi adalah suatu proses sosial yang sangat mendasar bahkan vital dalam 2 (dua) keberlangsungan hidup manusia di dalam masyarakat. Demikian juga di dalam sebuah organisasi, komunikasi menjadi pondasi utama dalam keberlangsungan jalannya suatu organisasi, karena pada kenyataannya masalah komunikasi selalu muncul dalam suatu proses organisasi. Oleh sebab itu, komunikasi yang efektif layaknya seperti sebuah jembatan penghubung yang menghubungkan serta membantu menyalurkan kinerja antar bagian dalam organisasi sehingga menghasilkan sebuah sinergi.

Komunikasi organisasi terjadi pada jaringan kerjasama yang besar, yang meliputi seluruh aspek, baik komunikasi interpersonal dan komunikasi kelompok. Komunikasi kelompok membahas topik-topik seperti struktur dan fungsi organisasi, hubungan antar manusia, komunikasi, serta proses organisasi dan budaya organisasi (Morissan, 2013). Alhasil dengan adanya komunikasi yang efektif dalam organisasi, selain ikut andil membangun iklim organisasi juga membentuk budaya organisasi. 
Terbentuknya sebuah organisasi yang kondusif merupakan buah pengelolaan komunikasi yang efektif di dalam organisasi maka adanya perbedaan-perbedaan individu dan ketidak mengertian (misunderstanding) dalam organisasi dapat diminimalisir, sehingga kinerja seluruh karyawan dapat berlangsung dengan baik.

Dalam melaksanakan pekerjaan, pegawai tidak lepas dari komunikasi dengan sesama rekan kerja, atasan dan bawahan. Komunikasi yang baik dapat menjadi sarana yang tepat dalam meningkatkan kinerja pegawai. Melalui komunikasi pegawai dapat meminta petunjuk kepada atasan mengenai pelaksanaan kerja. Melalui komunikasi juga pegawai dapat berkerjasama satu sama lain. Dalam kaitannya dengan efektifitas dan prestasi kerja para pegawai, perlu adanya komunikasi yang baik dari pimpinan dari organisasi bersangkutan, sebagai salah satu faktor pendorong bagi para pegawai untuk tetap berkerja dengan baik dan berprestasi tinggi (Performance).

Sekretariat Dewan Perwakilan Kota Lhokseumawe sebagai organisasi dituntut mampu melaksanakan kebijakan pimpinan sesuai dengan kewenangan tugas pokok dan fungsinya. Sekretariat DPRK Lhokseumawe dipimpin oleh seorang Sekretaris Dewan yang secara teknis operasionalnya berada dibawah dan bertanggung jawab kepada pimpinan DPRK dan secara administrasi bertanggung jawab kepada Walikota melalui Sekretaris Daerah (Sekda). Sekretaris Dewan Perwakilan Daerah yang selanjutnya disebut Sekretariat DPRK Lhokseumawe merupakan unsur pelayanan terhadap DPRK Lhokseumawe. Terdapat dua jenis status Pegawai di Sekretariat DPRK Lhokseumawe yaitu Pegawai Negeri Sipil dan Pegawai Bakti, dimana Pegawai Negeri Sipil diangkat oleh Pemerintah Pusat yang dibiayai dan mendapat anggaran resmi dari APBN dan APBD mencakup semua tunjangan yang didapatkannya berdasarkan golongan dan masa jabatan tertentu karena jenjang jabatannya memiliki suatu keteraturan, sedangkan Pegawai Bakti merupakan pegawai yang direkrut oleh instansi pemerintah daerah bukan dari jalur penerimaan cpns dengan gaji yang dibiayai dari APBD langsung dan berdasarkan kontrak kerja dengan jangka waktu tertentu atau setahun.

Dalam penelitian ini dititikberatkan pada Pegawai Bakti, dimana pegawai bakti dengan status kontrak kerja dengan masa kerja tertentu yang ditetapkan dalam ikatan perjanjian kerja yang ditandatangani oleh Kepala Daerah. Melihat begitu banyak dan kompleksnya tugas dari para pegawai bakti di Sekretariat DPRK Lhokseumawe maka perlu diperhatikan tentang Komunikasi dan gaya kepemimpinan dari masing-masing pimpinan, lingkungan kerja guna untuk meningkatkan motivasi para pegawai bakti tersebut sehingga tercapainya kepuasaan kerja dan tujuan institusi dapat tercapai dengan maksimal. 


\section{TINJAUAN PUSTAKA}

\section{KOMUNIKASI}

Robbins (2013) menyebutkan bahwa komuniksai membantu perkembangan motivasi dengan menjelaskan kepada para karyawan apa yang harus dilakukan, seberapa baik mereka bekerja, dan apa yang dapat dikerjakan untuk memperbaiki kinerja yang di bawah standar. Pace \& Faules (2010) mengemukakan bahwa Komunikasi organisasi adalah sebagai pertunjukkan dan penafsiran pesan di antara unit-unit komunikasi yang merupakan bagian dari suatu organisasi tertentu. Suatu organisasi terdiri dari unit-unit komunikasi dalam hubungan-hubungan hierarkis antar yang satu dengan yang lainnya dan berfungsi dalam suatu lingkungan. Menurut Romli (2011) bahwa komunikasi organisasi pengiriman dan penerimaan berbagai pesan organisasi didalam kelompok formal maupun informal dari suatu organisasi.

Menurut Suranto (2010), ada beberapa indikator komunikasi efektif, ialah:

1. Pemahaman,

2. Kesenangan,

3. Pengaruh pada sikap,

4. Hubungan yang makin baik,

5. Tindakan,

Adapun indikator komunikasi lainnya, Hidayat (2014) yaitu:

1. Komunikasi tertulis atau written communication,

2. Komunikasi Lisan atau oral communication,

3. Komunikasi non verbal,

4. Komunikasi antar pribadi,

5. Komunikasi lintas budaya.

\section{KEPEMIMPINAN}

Menurut Hasibuan (2011), pemimpin adalah seseorang yang mempergunakan wewenang dan kepemimpinannya untuk mengarahkan orang lain serta bertanggung jawab atas pekerjaan orang tersebut dalam mencapai suatu tujuan. Menurut Kartono (2010), pemimpin adalah seorang pribadi yang memiliki kecakapan dan kelebihan, khususnya kecakapan dan kelebihan di satu bidang sehingga dia mampu mempengaruhi orang lain untuk bersama-sama melakukan aktivitas-aktivitas tertentu demi pencapaian satu atau beberapa tujuan.

Menurut Robbins (2008) terdapat tiga macam model gaya kepemimpinan, yaitu transaksional, transformasional, dan laissez faire. Rivai (2009), membagi gaya kepemimpinan kedalam beberapa indikator, yang meliputi: (1) Watak, (2) Visi, (3) Kemampuan, (4) Memberi Motivasi, (5) Memberikan Arahan, (6) Melakukan Evaluasi. Sedangkan Rivai (2009), membagi gaya kepemimpinan kedalam beberapa indikator, yang meliputi : (1) Watak, (2) Visi, (3) Kemampuan, (4) Memberi Motivasi, (5) Memberikan Arahan, (6) Melakukan Evaluasi. 


\section{MOTIVASI KERJA}

Menurut Fernet, et al. (2012), motivasi adalah motif yang dikaitkan dengan keinginan seseorang untuk melakukan sesuatu atau tidak. Motivasi umumnya dibagi menjadi dua yaitu motivasi instrinsik dan ekstrinsik. Robbins (2006) mendefinisikan motivasi sebagai proses yang ikut menentukan intensitas, arah, dan ketekunan individu dalam usaha mencapai sasaran.

Menurut Siagian (2008), indikator motivasi adalah sebagai berikut :

1. Daya Pendorong,

2. Kemauan,

3. Kerelaan,

4. Keahlian,

5. Membentuk Keterampilan,

6. Tanggung Jawab,

7. Kewajiban.

Menurul Herzberg'S dalam Hasibuan (2009) berpendapat bahwa indikator-indikatornya adalah sebagai berikut:

1. Keberhasilan,

2. Pengakuan,

3. Pekerjaan itu sendiri,

4. Tanggungjawab,

5. Pengembangan.

\section{KEPUASAN KERJA}

Umam (2012) mengutarakan bahwa kepuasan kerja merupakan hasil dari pegawai yang berkaitan dengan motivasi kerja. Dengan kata lain kepuasan kerja adalah jumlah dari setiap aspek pekerjaan dikalikan derajat pentingnya aspek pekerjaan bagi individu. Hasibuan (2008), menyatakan bahwa Kepuasan kerja adalah Sikap emosional yang menyenangkan dan mencintai pekerjaanya.

Menurut Umam (2012) ada 5 (lima) indikator yang menentukan kepuasan kerja pegawai yaitu:

1. Gaji/ imbalan yang dirasakan adil,

2. Kondisi kerja yang menunjang,

3. Hubungan kerja (rekan kerja dan atasan),

4. Kepuasan kerja dan performansi kerja,

5. Dampak kepuasan dan ketidakpuasan kerja.

Menurut Badeni (2017) ada 6 (enam) indikator kepuasan kerja yaitu:

1. Pekerjaan itu sendiri,

2. Gaji,

3. Rekan kerja,

4. Atasan, 
5. Lingkungan kerja.

Penelitian ini dilaksanakan pada Sekretariat DPRK Lhokseumawe. Pemilihan lokasi penelitian ini dengan pertimbangan karena permasalahan di lokasi penelitian ini sesuai dengan judul penelitian. Sedangkan objek dalam penelitian ini adalah pegawai bakti Sekretariat DPRK Lhokseumawe. Populasi pada penelitian ini adalah para pegawai bakti Sekretariat DPRK Lhokseumawe sebanyak 123 orang.

\section{HASIL PENELITIAN DAN PEMBAHASAN}

Sejarah Sekretariat DPRK Lhokseumawe tidak dapat lepas dari sejarah keberadaan DPRD. Namun demikian keberadaan Sekretariat DPRK Lhokseumawe secara legal formal Sebagaimana diatur dalam ketentuan Pasal 9 Bab IV UU Nomor 2 Tahun 2001 tentang Pembentukan Kota Lhokseumawe. Sekretariat DPRK Lhokseumawe mempunyai tugas dan fungsi melayani aktifitas Dewan Perwakilan Rakyat Kota Lhokseumawe secara keseluruhan baik administratif maupun kegiatan lain utamanya yang berkaitan dengan kegiatan anggota dewan, demi terwujudnya tujuan meningkatnya kinerja legislatif dengan sasaran meningkatnya aspirasi masyarakat yang ditindaklanjuti dan meningkatnya kecepatan penyelesaian rancangan qanun.

Pada Tahun 2003 untuk masa bhakti 2003-2004 dalam rangka persiapan Pemilu dibentuklah DPRD Kota Lhokseumawe sebagai ketuanya yang pertama dijabat oleh H. Ilyas Wahab dari Partai Persatuan Pembangunan (PPP), saat itu DPRD Kota Lhokseumawe berkantor di Jl.Nyak Adam Kamil disamping kantor koramil Banda Sakti kota Lhokseumawe, dengan jumlah anggotanya sebanyak 25 orang.

Visi Sekretariat DPRK Lhokseumawe adalah terwujudnya lembaga DPRK Lhokseumawe yang aspiratif, demokratis, dan berkualitas dalam melaksanakan fungsi, tugas dan wewenangnya. Sementara itu untuk mendukung tercapainya visi, maka dilakukan dengan tiga misi yaitu:

1. meningkatkan peran dprk lhokseumawe dalam melaksanakan fungsi, tugas, dan wewenangnya.

2. menciptakan suasana demokratis dan penuh kebersamaan dalam setiap proses pengambilan kebijakan publik.

3. meningkatkan percepatan proses pengambilan kebijakan publik yang berkualitas.

Adapun full model SEM sebelum modifikasi dapat dilihat pada Gambar 5.15 di bawah ini:

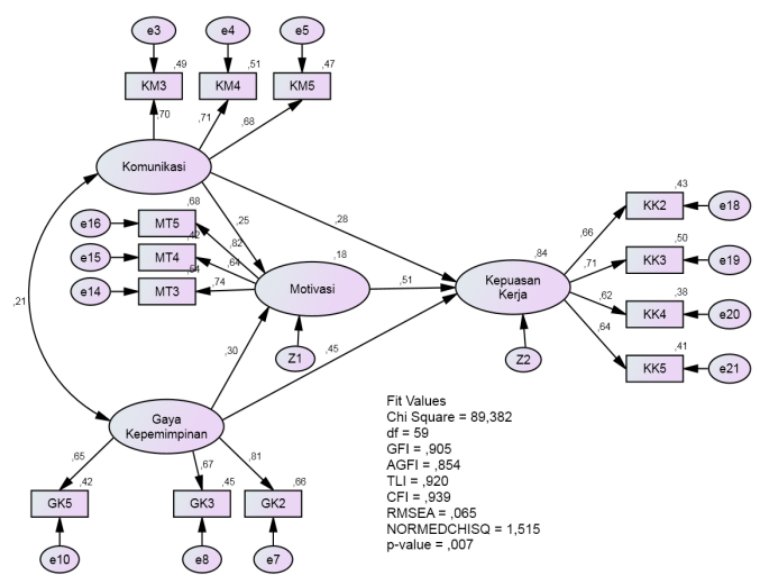

Selanjutnya penulis tampilkan gambar full model setelah modifikasi pada Gambar 5.15 di bawah ini: 


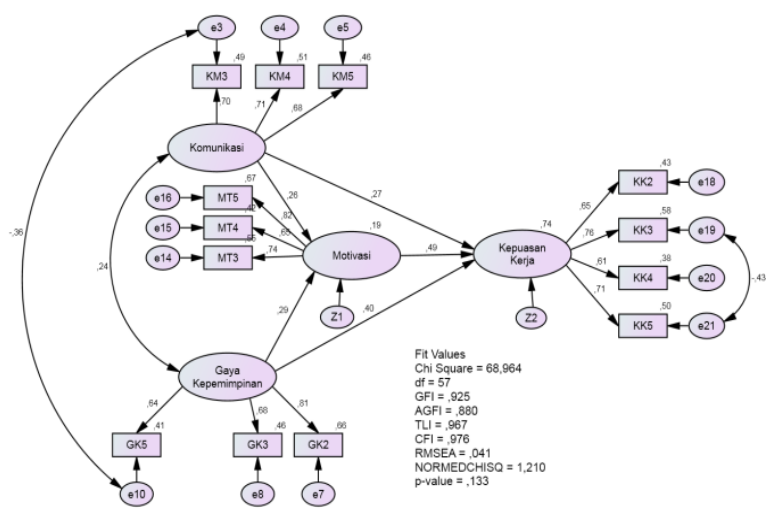

Selanjutnya untuk melihat seberapa besar pengaruh variabel eksogen (Komunikasi dan Gaya Kepemimpinan) terhadap variabel endogen (Motivasi dan Kepuasan Kerja) ditampilkan dalam Tabel 5.24 di bawah ini:

Tabel 5.24

Pengaruh Variabel Eksogen terhadap Variabel Endogen

\begin{tabular}{|c|c|c|c|c|}
\hline & & & $\begin{array}{l}\text { Standardized } \\
\text { Estimate }\end{array}$ & $\mathrm{P}$ \\
\hline Motivasi & $<--$ & Komunikasi & ,256 & ,037 \\
\hline Motivasi & $<--$ & $\begin{array}{c}\text { Gaya } \\
\text { Kepemimpinan }\end{array}$ & ,294 &, 015 \\
\hline $\begin{array}{c}\text { Kepuasa } \\
\text { Kerja }\end{array}$ & $<--$ & Komunikasi & ,266 &, 007 \\
\hline $\begin{array}{c}\text { Kepuasa } \\
\text { Kerja }\end{array}$ & $<--$ & $\begin{array}{c}\text { Gaya } \\
\text { Kepemimpinan }\end{array}$ & ,397 & $* * *$ \\
\hline $\begin{array}{c}\text { Kepuasa } \\
\text { Kerja }\end{array}$ & $<--$ & Motivasi & , 488 & $* * *$ \\
\hline
\end{tabular}

Berdasarkan Tabel 5.24 diatas maka dapat dijelaskan bahwa dari 5 pengaruh langsung variabel eksogen terhadap variabel endogen seluruhnya berpengaruh positif signifikan.

\section{PENGARUH KOMUNIKASI TERHADAP MOTIVASI}

Berdasarkan hasil pengujian dengan menggunakan SEM melaui program Amos, terbukti komunikasi memiliki pengaruh positif signifikan terhadap motivasi. Hasil analisis membuktikan bahwa nilai estimate yang dihasilkan model adalah 0,256 dengan nilai probabilitas $0,037(<0,05)$ sehingga dapat dinyatakan komunikasi berpengaruh positif signifikan terhadap motivasi. Hal ini berarti semakin baik komunikasi maka pegawai akan merasa nyaman dan puas dalam bekerja sehingga hal ini akan mengakibatkan semakin baik pula motivasi kerja pegawai pada Sekretariat DPRK Lhokseumawe.

Hasil penelitian ini sejalan dengan penelitian Putra (2013) yang menyimpulkan pengaruh antara komunikasi pimpinan terhadap motivasi kerja dikategorikan positif dan signifikan, berarti semakin baik komunikasi yang dilakukan oleh pimpinan maka tingkat motivasi kerja yang dimiliki pegawai akan menjadi lebih baik. Sebaliknya, pimpinan yang kurang memiliki kemampuan dalam berkomunikasi di dalam kantor maka tingkat motivasi pegawainya juga akan rendah. 


\section{PENGARUH GAYA KEPEMIMPINAN TERHADAP MOTIVASI}

Berdasarkan hasil pengujian dengan menggunakan SEM melaui program Amos, terbukti gaya kepemimpinan memiliki pengaruh positif signifikan terhadap motivasi. Hasil analisis membuktikan bahwa nilai estimate yang dihasilkan model adalah 0,294 dengan nilai probabilitas $0,015 \quad(<0,05)$ sehingga dapat dinyatakan gaya kepemimpinan berpengaruh positif signifikan terhadap motivasi. Hal ini berarti semakin baik gaya kepemimpinan yang diterapkan di instansi tersebut maka akan semakin tinggi pula motivasi pegawai pada Sekretariat DPRK Lhokseumawe.

Hasil penelitian ini sejalan dengan penelitian Syaiyid,dkk (2013), yang menyimpulkan bahwa gaya kepemimpinan direktif, gaya kepemimpinan suportif dan gaya kepemimpinan partisipatif bersama-sama mempunyai pengaruh secara signifikan terhadap motivasi kerja karyawan. Hasil penelitian Wahyuning Tyas, et al. (2016) juga menyatakan bahwa secara simultan gaya kepemimpinan dan motivasi kerja berpengaruh signifikan terhadap kepuasan kerja pegawai.

\section{PENGARUH KOMUNIKASI TERHADAP KEPUASAN KERJA}

Berdasarkan hasil pengujian dengan menggunakan SEM melaui program Amos, terbukti komunikasi memiliki pengaruh positif signifikan terhadap kepuasan kerja. Hasil analisis membuktikan bahwa nilai estimate yang dihasilkan model adalah 0,266 , dengan nilai probabilitas $0,007 \quad(<0,05)$ sehingga dapat dinyatakan komunikasi berpengaruh positif signifikan terhadap kepuasan kerja. Hal ini berarti semakin baik komunikasi maka akan meningkat pula kepuasan kerja pegawai pada Sekretariat DPRK Lhokseumawe.

Hasil penelitian ini sejalan dengan penelitian Ardiansyah (2016) yang menyimpulkan terdapat pengaruh signifikan komunikasi terhadap kepuasan kerja karyawan disebabkan komunikasi dapat meningkatkan kepuasan kerja karyawan dan hubungan baik antara atasan dengan bawahan, Bila komunikasi efektif dapat terwujud maka produktifitas karyawan akan semakin tinggi.

\section{PENGARUH GAYA KEPEMIMPINAN TERHADAP KEPUASAN KERJA}

Berdasarkan hasil pengujian dengan menggunakan SEM melaui program Amos, terbukti gaya kepemimpinan memiliki pengaruh positif signifikan terhadap kepuasan kerja. Hasil analisis membuktikan bahwa nilai estimate yang dihasilkan model adalah 0,397, dengan nilai probabilitas 0,0001 $(<0,05)$ sehingga dapat dinyatakan gaya kepemimpinan berpengaruh positif signifikan terhadap kepuasan kerja. Hal ini berarti semakin baik gaya kepemimpinan pegawai maka akan semakin meningkat pula kepuasan kerja pegawai pada Sekretariat DPRK Lhokseumawe.

Hasil penelitian ini sejalan dengan penelitian Nafisah (2005), yang menyimpulkan dalam penelitiannya bahwa lima faktor kepemimpinan yaitu gaya partisipatif, gaya orientasi prestasi, gaya direktif, gaya suportif dan gaya pengasuh berpengaruh positif dan signifikan terhadap kepuasan kerja. 


\section{PENGARUH MOTIVASI TERHADAP KEPUASAN KERJA}

Berdasarkan hasil pengujian dengan menggunakan SEM melaui program Amos, terbukti motivasi memiliki pengaruh positif signifikan terhadap kepuasan kerja. Hasil analisis membuktikan bahwa nilai estimate yang dihasilkan model adalah 0,488 dengan nilai probabilitas $0,0001(<0,05)$ sehingga dapat dinyatakan motivasi berpengaruh positif signifikan terhadap kepuasan kerja. Hal ini berarti semakin tinggi motivasi pegawai maka akan semakin meningkatan pula kepuasan kerja pada Sekretariat DPRK Lhokseumawe.

Hasil penelitian ini sejalan dengan penelitian Ramlan (2011) menyatakan bahwa terdapat hubungan positif dan pengaruh signifikan antara variabel gaya kepemimpinan dengan kepuasan kerja pegawai Balai Besar Industri Hasil Pertanian Bogor.

\section{MOTIVASI MEMEDIASI PENGARUH KOMUNIKASI TERHADAP KEPUASAN KERJA}

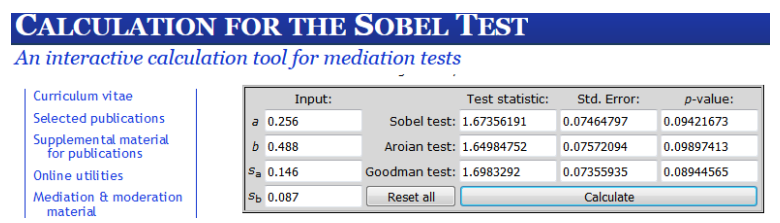

Berdasarkan hasil kalkulasi sobel tes pengaruh mediasi motivasi antara komunikasi terhadap kepuasan kerja menghasilkan nilai estimate 0,125 dan nilai probabilitas 0.094 yang berarti tidak signifikan. Sehingga dapat dinyatakan motivasi memediasi secara tidak signifikan pengaruh komunikasi terhadap kepuasan kerja pada Sekretariat DPRK Lhokseumawe.

Berdasarkan Gambar 5.17 dapat dijelaskan signifikasi jalur a terdiri dari hubungan komunikasi terhadap motivasi diperoleh nilai signifikasi 0,037. Signifikasi jalur b yaitu motivasi terhadap kepuasan kerja dengan nilai signifikasi 0,0001. Signifikasi jalur c yaitu komunikasi terhadap kepuasan kerja dengan nilai signifikasi 0,007. Signifikasi jalur c' yaitu komunikasi terhadap kepuasan kerja melalui motivasi dengan nilai signifikasi 0,094. Tiga nilai signifikasi tersebut $<0,05$ yang berarti signifikan, dan satu nilai signifikansi >0,05 yang bearti tidak signifikan. Maka mediasi ini disebut mediasi Sempurna (Full mediation). Mediasi sempurna adalah mediasi secara tidak signifikan yang dilakukan oleh variabel mediasi (motivasi) antara variabel bebas (komunikasi) terhadap variabel terikat (kepuasan kerja).

Hasil penelitian Ardiansyah (2016) menunjukkan bahwa variable komunikasi dan kepuasan kerja berpengaruh positif dan signifikan terhadap motivasi serta variabel motivasi memediasi variabel eksogen dengan variabel endogen secara parsial mediasi. Hasil penelitian ini juga didukung penelitian Carriere dan Bourque (2009) yang menunjukan bahwa dalam komunikasi berpengaruh terhadap kepuasan kerja pegawai yang dimediasi oleh motivasi. 


\section{MOTIVASI MEMEDIASI PENGARUH GAYA KEPEMIMPINAN TERHADAP KEPUASAN KERJA}

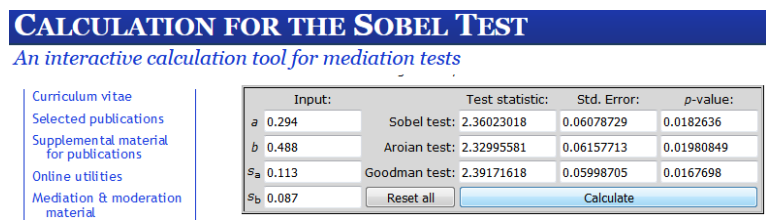

Berdasarkan hasil kalkulasi sobel tes pengaruh mediasi motivasi antara gaya kepemimpinan terhadap kepuasan kerja menghasilkan nilai probabilitas 0.018 yang berarti signifikan. Sehingga dapat dinyatakan motivasi memediasi secara signifikan pengaruh gaya kepemimpinan terhadap kepuasan kerja pada Sekretariat DPRK Lhokseumawe.

Berdasarkan Gambar 5.19 dapat dijelaskan signifikasi jalur a terdiri dari hubungan gaya kepemimpinan terhadap motivasi diperoleh nilai signifikasi 0,015 . Signifikasi jalur b yaitu motivasi terhadap kepuasan kerja dengan nilai signifikasi 0,0001. Signifikasi jalur c yaitu gaya kepemimpinan terhadap kepuasan kerja dengan nilai signifikasi 0,0001. Signifikasi jalur c' yaitu gaya kepemimpinan terhadap kepuasan kerja melalui motivasi dengan nilai signifikasi 0,018. Keempat nilai signifikasi tersebut $<0,05$ yang berarti signifikan. Maka mediasi ini disebut mediasi Parsial (Partial mediation). Mediasi parsial adalah mediasi secara signifikan yang dilakukan oleh variabel mediasi (motivasi) antara variabel bebas (gaya kepemimpinan) terhadap variabel terikat (kepuasan kerja).

Hasil penelitian ini sejalan dengan hasil penelitian Putri (2017) yang berkesimpulan bahwa variabel gaya kepemimpinan transformasional mempunyai pengaruh signifikan terhadap motivasi kerja dan menunjukkan bahwa motivasi mampu dan bisa menjadi variabel yang memediasi antara gaya kepemimpinan transformasional terhadap kepuasan kerja pegawai, Sehingga jika pimpinan mampu mendorong motivasi pegawai maka kepuasan kerja pegawai akan lebih meningkat lagi dan banyaknya beban kerja yang didistribusikan akan mempengaruhi motivasi pegawai terhadap penyelesaian tugasnya.

Pembuktian keseluruhan hipotesis dapat dilakukan dengan berdasarkan nilai probabilitas dari suatu pengaruh satu variabel dengan variabel lainnya. Pembuktian keseluruhan dapat dilihat pada Tabel 5.26 di bawah ini, yaitu: 


\begin{tabular}{|c|c|c|}
\hline No & Pernyataan Hipotesis & Kesimpulan \\
\hline 1 & $\begin{array}{l}\text { Komunikasi berpengaruh positif } \\
\text { terhadap motivasi pegawai pada } \\
\text { Sekretariat DPRK Lhokseumawe. }\end{array}$ & $\begin{array}{l}\text { Hipotesis } \\
\text { Diterima }\end{array}$ \\
\hline 2 & $\begin{array}{l}\text { Gaya kepemimpinan berpengaruh } \\
\text { positif terhadap motivasi pegawai } \\
\text { pada Sekretariat DPRK Lhokseumawe. }\end{array}$ & $\begin{array}{l}\text { Hipotesis } \\
\text { Diterima }\end{array}$ \\
\hline 3 & $\begin{array}{l}\text { Komunikasi berpengaruh positif } \\
\text { terhadap kepuasan kerja pegawai } \\
\text { pada Sekretariat DPRK Lhokseumawe. }\end{array}$ & $\begin{array}{l}\text { Hipotesis } \\
\text { Diterima }\end{array}$ \\
\hline 4 & $\begin{array}{l}\text { Gaya Kepemimpinan berpengaruh } \\
\text { positif terhadap kepuasan kerja } \\
\text { pegawai pada Sekretariat DPRK } \\
\text { Lhokseumawe. }\end{array}$ & $\begin{array}{l}\text { Hipotesis } \\
\text { Diterima }\end{array}$ \\
\hline 5 & $\begin{array}{l}\text { Motivasi berpengaruh positif terhadap } \\
\text { kepuasan kerja pegawai pada } \\
\text { Sekretariat DPRK Lhokseumawe. }\end{array}$ & $\begin{array}{l}\text { Hipotesis } \\
\text { Diterima }\end{array}$ \\
\hline 6 & $\begin{array}{l}\text { Motivasi memediasi komunikasi } \\
\text { terhadap kepuasan kerja pegawai } \\
\text { pada Sekretariat DPRK Lhokseumawe. }\end{array}$ & $\begin{array}{l}\text { Hipotesis } \\
\text { Diterima }\end{array}$ \\
\hline 7 & 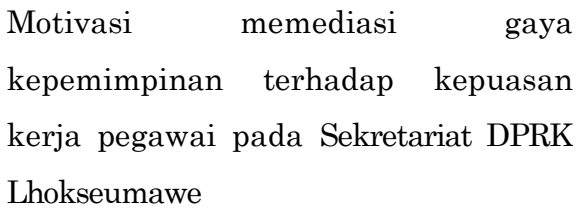 & $\begin{array}{l}\text { Hipotesis } \\
\text { Diterima }\end{array}$ \\
\hline
\end{tabular}

Sesuai hasil pembuktian hipotesis pada Tabel 5.26 di atas maka dapat disimpulkan hipotesis 1 sampai 5 berpengaruh positif signifikan, hipotesis 6 memediasi secara sempurna (full mediation), dan hipotesis 7 memediasi secara parsial (partial mediation) sehingga semua hipotesis diterima dan data mendukung model.

\section{KESIMPULAN}

Berdasarkan tujuan dan hasil penelitian serta pembahasan yang telah diuraikan pada Bab sebelumnya, maka dapat dikemukakan beberapa kesimpulan sebagai berikut:

1. Komunikasi berpengaruh positif dan signifikan terhadap motivasi pegawai bakti pada Sekretariat DPRK Lhokseumawe.

2. Gaya kepemimpinan berpengaruh positif dan signifikan terhadap motivasi pegawai bakti pada Sekretariat DPRK Lhokseumawe.

3. Komunikasi berpengaruh positif dan signifikan terhadap kepuasan kerja pegawai bakti pada Sekretariat DPRK Lhokseumawe.

4. Gaya kepemimpinan berpengaruh positif dan signifikan terhadap kepuasan kerja pegawai bakti pada Sekretariat DPRK Lhokseumawe. 
5. Motivasi berpengaruh positif dan signifikan terhadap kepuasan kerja pegawai bakti pada Sekretariat DPRK Lhokseumawe.

6. Motivasi memediasi secara positif namun tidak signifikan pengaruh komunikasi terhadap kepuasan kerja pegawai bakti pada Sekretariat DPRK Lhokseumawe. Mediasi ini disebut mediasi Sempurna (Full mediation).

7. Motivasi memediasi secara positif dan signifikan pengaruh gaya kepemimpinan terhadap kepuasan kerja pegawai bakti pada Sekretariat DPRK Lhokseumawe. Mediasi ini disebut mediasi Parsial (partial mediation).

\section{SARAN}

Dalam rangka meningkatkan motivasi dan kepuasan kerja pegawai bakti pada Sekretariat DPRK Lhokseumawe, penulis menyarankan beberapa hal sebagai berikut:

1. Pengaruh komunikasi terhadap motivasi pegawai bakti paling rendah diantara pengaruh lainnya, meskipun demikian pengaruhnya juga positif signifikan. Rendahnya pengaruh tersebut disebabkan oleh pengaruh dua indikator yang tidak maksimal yaitu indikator komunikasi tertulis dan komunikasi lisan.

\section{KETERBATASAN PENELITIAN}

Berdasarkan hasil pembahasan dan kesimpulan, maka dapat diutarakan beberapa keterbatasan dalam penelitian ini yaitu:

1. Penelitian ini dilakukan hanya pada satu Sekretariat DPRK Lhokseumawe, diharapkan pada penelitian selanjutnya dilakukan pada dua atau tiga instansi di Kabupaten/ Kota lainnya agar mendapatkan hasil yang lebih maksimal.

2. Penelitian ini dilakukan pada seluruh pegawai bakti diharapkan pada penelitian selanjutnya dilakukan juga pada PNS dengan memilih golongan tertentu agar hasilnya juga lebih terukur.

\section{DAFTAR PUSTAKA}

Ardiansyah, Dimas Okta. (2016) Pengaruh Komunikasi terhadap Kinerja Karyawan dengan Dimediasi oleh Kepuasan Kerja (Studi Pada Bagian Produksi Pabrik Kertas PT. Setia Kawan Makmur Sejahtera Tulungagung). Jurnal Bisnis dan Manajemen, Vol. 3 No.1, Januari 2016:16-30.

Badeni (2017) Kepemimpinan dan Perilaku Organisasi. Alfabeta: Bandung.

Bangun, Wilson (2012) Manajemen Sumber Daya Manusia. Erlangga. Bandung.

Carriere, Jules and Bourque, Christoper. (2009) The effects of organizational communication on job satisfaction and organizational commitment in a land ambulance service and the mediating role of communication satisfaction, Journal of career Development International. Vol 14, No 1, pp 29-49. 
Dewi, Yayu Rohmanowati (2005) Studi Kepuasan Kerja dalam Hubungannya dengan Motivasi Kerja dan Efektivitas Kepemimpinan (Studi Kasus di Pusdiklat Pegawai Depdiknas Sawangan).

Fahmi, Irham. (2014). Manajemen: Teori, Kasus, dan Solusi. Alfabeta: Bandung.

Fernet C., F. Guay, C. Senecal dan S.Austin (2012), Predicting intra-individual changes in teacher burnout:The Role of Perceived School Environment and Motivational factors. Teaching and Teacher Education.

Ghozali, Imam. (2014). Model Persamaan Struktural Konsep dan Aplikasi Dengan Program AMOS 22.0. (Edisi VI) Badan Penerbit Universitas Dipenogoro: Semarang.

Hasibuan, M. (2011). Manajemen Dasar, Pengertian, dan Masalah. Jakarta: PT.Bumi Aksara.

Hasibuan, Malayu S. P. (2012). Manajemen Sumber Daya Manusia. (Edisi Revisi). Bumi Aksara: Jakarta.

Kartono, Kartini. (2011) Pemimpin dan Kepemimpinan. Jakarta: PT Raja Grafindo Persada.

Luthans, Fred. (2006). Perilaku Organisasi. Andi: Yogyakarta.

Mangkunegara, Anwar Prabu (2009) Manajemen Sumber Daya Manusia Perusahaan. Rosdakarya: Bandung.

Marwansyah (2017) Manajemen Sumber Daya Manusia. Alfabeta: Bandung.

Preacher, K.J. and Hayes. (2010). Calculation for the Sobel Test. www.calculationf or sobel test. (diakses 20-1- 2018).

Program Pascasarjana Ilmu Manajemen. (2011). Buku Panduan Penulisan Tesis. Fakultas Ekonomi Universitas Malikussaleh: Lhokseumawe.

Pace R. Wayne dan Faules Don F, (2010) Komunikasi Organisasi: Strategi Meningkatkan Kinerja Perusahaan, PT Remaja Rosdakarya, Bandung.

Ramlan, Ruvendi (2011) Pengaruh Imbalan dan Gaya Kepemimpinan Pengaruhnya Terhadap Kepuasan Kerja Karyawan, Di Balai Besar Industri Hasil Pertanian Bogor. Jurnal Universitas Diponegoro: Semarang.

Regina, Reza Aditya. (2010) Pengaruh Gaya Kepemimpinan, Motivasi dan Disiplin Kerja Terhadap Kinerja Karyawan PT. Sinar Santosa Perkasa Banjarnegara, Semarang : Universitas Diponogoro.

Riduwan. (2013). Metode \& Teknik Menyusun Tesis. (Cetakan Kesembilan). Alfabeta: Bandung.

Rivai, Veithzal. (2004) Kepemimpinan Dan Perilaku Organisasi. Jakarta : Raja Grafindo Persada. 
Rivai V dan Sagala E.J (2013). Manajemen Sumber Daya Manusia untuk Perusahaan Dari Teori ke Praktik. Edisi Kedua. Cetakan Kelima. Jakarta: PT. Raha Grafindo Persada.

Robbins, Stephen P. dan Timothy A. Judge. (2013) Perilaku Organisasi. Jakarta: Penerbit Salemba Empat.

Robbins, Stephen. (2007) Manajemen. Edisi kedelapan/ jilid 2. Jakarta, PT. Grafindo.

Robbins, Stephen P. \& Judge, Timothy A. (2017). Perilaku Organisasi (Edisi 16). Salemba Empat: Jakarta.

Sambung, Roby. (2011). Pengaruh Kepuasan Kerja terhadap OCB-I dan OCB-O dengan Dukungan Organisasi Sebagai Variabel Moderating. Jurnal Universitas Palangka Raya: Palangkaraya.

Siagian Sondang P., (2008) Manajemen Sumber Daya Manusia, PT. Bumi Aksara Jakarta.

Simamora, Henry. (2015). Manajeman Sumber Daya Manusia. STIE YKPN: Yogyakarta.

Solimun (2011). Analisis Variabel Moderasi dan Mediasi. Jurnal Program Studi Statistika FMIPA UB: Malang.

Sugiyono (2009). Metode Penelitian Kuantitatif, Kualitatif dan R \& D. Alfabeta: Bandung.

Sugiyono (2012) Metode Penelitian kombinasi (Mixed Methods). Alfabeta: Bandung.

Suparyadi (2015) Manajemen Sumber Daya Manusia- Menciptakan Keunggulan Berbasis Kompetensi SDM. ANDI: Yogyakarta.

Sutrisno, Edy (2012). Manajemen Sumber Daya Manusia. Kencana: Jakarta.

Umam, Khaerul (2012) Perilaku Organisasi. Pustaka Setia: Bandung.

Usman, Husaini (2011). Manajemen Teori, praktik dan Riset Pendidikan (Edisi 3. Bumi Aksara: Jakarta. Wibowo (2008) Manajemen Kinerja. Rajagrafindo Persada: Jakarta.

Wibowo (2013) Perilaku Dalam Organisasi. Raja Grafindo Persada: Jakarta. 